ҚАЗАҚСТАН РЕСПУБЛИКАСЫ

ҰЛТТЫҚ ҒЫЛЫМ АКАДЕМИЯСЫНЫН

АБАЙ АТЫНДАҒЫ ҚАЗАҚ ҰЛТТЫҚ

ПЕДАГОГИКАЛЫҚ УНИВЕРСИТЕТІНІҢ

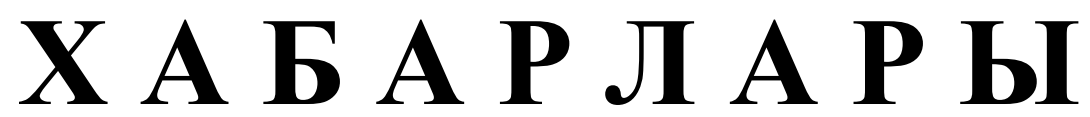

\section{ИЗВЕСТИЯ}

НАЦИОНАЛЬНОЙ АКАДЕМИИ НАУК РЕСПУБЛИКИ КАЗАХСТАН

КАЗАХСКИЙ НАЦИОНАЛЬНЫЙ

ПЕДАГОГИЧЕСКИЙ УНИВЕРСИТЕТ ИМ. АБАЯ

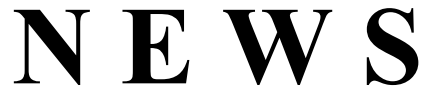

OF THE NATIONAL ACADEMY OF SCIENCES OF THE REPUBLIC OF KAZAKHSTAN

ABAY KAZAKH NATIONAL PEDAGOGICAL UNIVERSITY

ҚОҒАМДЫҚ ЖӘНЕ ГУМАНИТАРЛЫҚ ҒЫЛЫМДАР СЕРИЯСЫ

СЕРИЯ ОБЩЕСТВЕННЫХ И ГУМАНИТАРНЫХ НАУК

SERIES OF SOCIAL AND HUMAN SCIENCES

\author{
6 (322) \\ ҚАРАША - ЖЕЛТОҚСАН 2018 ж. \\ НОЯБРЬ - ДЕКАБРЬ 2018 Г. \\ NOVEMBER - DECEMBER 2018 \\ ИЗДАЕТСЯ С ЯНВАРЯ 1962 ГОДА \\ PUBLISHED SINCE JANUARY 1962 \\ ЖЫЛЫНА 6 РЕТ ШЫҒАДЫ \\ ВЫХОДИТ 6 РАЗ В ГОД \\ PUBLISHED 6 TIMES A YEAR
}

1962 ЖЫЛДЫҢ ҚАНТАР АЙЫНАН ШЫҒА БАСТАҒАН 
Ба с ре дактор

ҚР ҰҒА кұрметті мүшесі

Балықбаев Т.O.

Р е д а ц и я а лқ а сы:

экон. ғ. докторы, проф., ҚР ҰҒА академигі Баймұратов У.Б.; тарих ғ. докторы, проф., ҚР ҰҒА академигі Байпақов К.М.; филос. ғ.докторы, проф., ҚР ҰҒА академигі Есім Г.Е.; фил. ғ. докторы,, проф., ҚР ҰҒА академигі Қирабаев С.С.; эк. ғ. докторы, проф., ҚР ҰҒА академигі Кошанов А.К.; эк.ғ. докторы, проф., ҚР ҰҒА академигі Нәрібаев К.Н. (бас редактордың орынбасары); филос. ғ.докторы, проф., ҚР ҰҒА академигі Нысанбаев А.Н.; заң ғ. докторы, проф., ҚР ҰҒА академигі Сәбікенов С.Н.; заң ғ. докторы, проф., ҚР ҰҒА академигі Сүлейменов М.К.; эк. ғ. докторы, проф., ҚР ҰҒА академигі Сатыбалдин С.С.; тарих ғ. докторы, проф., ҚР ҰҒА академик Әбжанов Х.М.; тарих ғ. докторы, проф., ҚР ҰҒА корр. мүшесі Әбусеитова М.Х.; тарих ғ. докторы, проф., ҚР ҰҒА академик Байтанаев Б.А.; филол. ғ. докторы, проф., ҚР ҰҒА корр. мүшесі Жақып Б.А.; фил. ғ. докторы, проф., академик НАН РК Қалижанов У.К.; филол. ғ. докторы, проф., ҚР ҰҒА академик Қамзабекұлы Д.; тарих ғ. докторы, проф., ҚР ҰҒА академик Қожамжарова Д.П.; тарих ғ. докторы, проф., ҚР ҰҒА академик Койгелдиев М.К.; фил. ғ. докторы, проф., ҚР ҰҒА корр. мүшесі Кұрманбайұлы Ш.; тарих ғ. докторы, проф., ҚР ҰҒА корр. мүшесі Таймағанбетов Ж.К.; социол. ғ. докторы, проф., ҚР ҰҒА корр. мүшесі Шәукенова 3.К.; фил. ғ. докторы, проф., КР ҰҒА корр. мүшесі Дербісәлі А.; саяси. ғ. докторы, проф., Бижанов А.К., тарих ғ. докторы, проф., Кабульдинов 3.Е.; фил. ғ. докторы, проф., ҚР ҰҒА корр мүшесі Қажыбек Е.3.

\section{Р едакция ке н е с i:}

Молдова Республикасының ҰҒА академигі Белостечник Г. (Молдова); Әзірбайжан ҰҒА академигі Велиханлы Н. (Азербайджан); Тәжікстан ҰҒА академигі Назаров Т.Н. (Тәжікстан); Молдова Республикасының ҰҒА академигі Рошка А. (Молдова); Молдова Республикасының ҰҒА академигі Руснак Г. (Молдова); Әзірбайжан ҰҒА корр. мүшесі Мурадов Ш. (Әзірбайжан); Әзірбайжан ҰҒА корр. мүшесі Сафарова 3. (Әзірбайжан); э. ғ. д., проф. Василенко В.Н. (Украина); заң ғ. докт., проф. Устименко В.А. (Украина)

«Қазақстан Республикасы Ұлттық ғылым академиясының Хабарлары. Қоғамдық және гуманитарлық ғылымдар сериясы». ISSN 2224-5294

Меншіктенуші: «Қазақстан Республикасының Ұлттық ғылым академиясы» РҚБ (Алматы қ.)

Қазақстан республикасының Мәдениет пен ақпарат министрлігінің Ақпарат және мұрағат комитетінде 30.04.2010 ж. берілген № 10894-Ж мерзімдік басылым тіркеуіне қойылу туралы куәлік

Мерзімділігі: жылына 6 рет.

Тиражы: 500 дана.

Редакцияның мекенжайы: 050010, Алматы қ., Шевченко көш., 28, 219 бөл., 220, тел.: 272-13-19, 272-13-18, http://nauka-nanrk.kz. social-human.kz

(C) Қазақстан Республикасының Ұлттық ғылым академиясы, 2018

Типографияның мекенжайы: «Аруна» ЖК, Алматы қ., Муратбаева көш., 75. 
Главный редактор

Почетный член НАН РК

T.O. Балыкбаев

Р е дак ци онн а я коллег и я:

докт. экон. Н., проф., академик НАН РК У.Б. Баймуратов; докт. ист. н., проф., академик НАН РК К.М. Байпаков; докт. филос. Н., проф., академик НАН РК Г.Е. Есим; докт. фил. Н., проф., академик НАН РК С.С. Кирабаев; докт. экон. Н., проф., академик НАН РК А.К. Кошанов; докт. экон. Н., проф., академик НАН РК К.Н. Нарибаев (заместитель главного редактора); докт. филос. н., проф., академик НАН РК А.Н. Нысанбаев; докт. юр. Н., проф., академик НАН РК С.Н. Сабикенов; докт. юр. н., проф., академик НАН РК М.К. Сулейменов; докт. экон. Н., проф., академик НАН РК С.С. Сатубалдин; докт. ист. н., проф., академик НАН РК Х.М. Абжанов; докт. ист. н., проф., чл.-корр. НАН РК М.Х. Абусеитова; докт. ист. н., проф., академик НАН РК Б.А. Байтанаев; докт. фил. н., проф., чл.-корр. НАН РК Б.А. Жакып; докт. фиолол. н., проф., академик НАН РК У.К. Калижанов; докт. фил. н., проф., академик НАН РК Д. Камзабекулы; докт. ист. н., проф., академик НАН РК Д.П. Кожамжарова; докт. ист. н., проф., академик НАН РК М.К. Койгельдиев; докт. филол. н., проф., чл.-корр. НАН РК Ш. Курманбайулы; докт. ист. н., проф., чл.корр. НАН РК Ж.К. Таймаганбетов; докт. социол. н., проф., чл.-корр. НАН РК З.К. Шаукенова; д. филол. н., проф., чл.-корр. НАН РК А. Дербисали; доктор политических наук, проф., Бижанов А.К.; доктор ист. наук, проф., Кабульдинов 3.Е.; доктор филол. н., проф., член-корр. НАН РК Қажыбек Е.3.

Р е дак ци онны й с ов ет

академик НАН Республики Молдова Г. Белостечник (Молдова); академик НАН Азербайджанской Республики Н. Велиханлы (Азербайджан); академик НАН Республики Таджикистан Т.Н. Назаров (Таджикистан); академик НАН Республики Молдова А. Рошка (Молдова); академик НАН Республики Молдова Г. Руснак (Молдова); чл.-корр. НАН Азербайджанской Республики Ш. Мурадов (Азербайджан), член-корр. НАН Азербайджанской Республики 3.Сафарова (Азербайджан); д. э. н., проф. В.Н. Василенко (Украина); д.ю.н., проф. В.А. Устименко (Украина)

Известия Национальной академии наук Республики Казахстан. Серия общественных и гуманитарных наук. ISSN 2224-5294

Собственник: РОО «Национальная академия наук Республики Казахстан» (г. Алматы)

Свидетельство о постановке на учет периодического печатного издания в Комитете информации и архивов

Министерства культуры и информации Республики Казахстан № 10894-Ж, выданное 30.04.2010 г.

Периодичность 6 раз в год

Тираж: 500 экземпляров

Адрес редакции: 050010, г. Алматы, ул. Шевченко, 28, ком. 219, 220, тел. 272-13-19, 272-13-18, www:nauka-nanrk.kz / social-human.kz

(C) Национальная академия наук Республики Казахстан, 2018 г.

Адрес типографии: ИП «Аруна», г. Алматы, ул. Муратбаева, 75

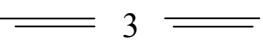


Chief Editor

\section{Honorary member of NAS RK \\ Balykbayev T.O}

Editorial board:

Doctor of economics, prof, academician of NAS RK Baimuratov U.B.; doctor of history, prof, academician of NAS RK Baipakov K.M.; doctor of philosophy, prof, academician of NAS RK Esim G.E.; doctor of philology, prof, academician of NAS RK Kirabayev S.S.; doctor of economics, prof, academician of NAS RK Koshanov A.K.; doctor of economics, prof, academician of NAS RK Naribayev K.N. (deputy editor-in-chief); doctor of philosophy, prof, academician of NAS RK Nyssanbayev A.N.; doctor of law, prof, academician of NAS RK Sabikenov S.N.; doctor of law, prof, academician of NAS RK Suleymenov M.K.; doctor of economy, prof, academician of NAS RK Satybaldin S.S.; doctor of history, prof, academician of NAS RK Abzhanov H.M; doctor of history, prof, corresponding member of NAS RK Abuseitova M.H.; doctor of history, prof, academician of NAS RK Baitanaev B.A.; doctor of philology, prof, corresponding member of NAS RK Zhakyp B.A.; doctor of philology, prof, academician of NAS RK Kalizhanov U.K.; doctor of philology, prof, academician of NAS RK Hamzabekuly D.; doctor of history, prof, academician of NAS RK Kozhamzharova D.P.; doctor of history, prof, academician of NAS RK Koigeldiev M.K.; doctor of philology, prof, corresponding member of NAS RK Kurmanbaiuly Sh.; doctor of history, prof, academician of NAS RK Taimaganbetov J.K.; doctor of sociology, prof, corresponding member of NAS RK Shaukenova Z.K.; doctor of philology, prof, corresponding member of NAS RK Derbisali A.; doctor of political science, prof Bizhanov A.K; doctor of History, prof Kabuldinov Z.E.; doctor of philology, prof, corresponding member of NAS RK Kazhybek E.Z.

\section{Editorial staff:}

Academician NAS Republic of Moldova Belostechnik.G (Moldova); Academician NAS Republic of Azerbaijan Velikhanli N. (Azerbaijan); Academician NAS Republic of Tajikistan Nazarov T.N. (Tajikistan); Academician NAS Republic of Moldova Roshka A. (Moldova) Academician NAS Republic of Moldova Rusnak G. (Moldova); Corresponding member of the NAS Republic of Azerbaijan Muradov Sh. (Azerbaijan); Corresponding member of the NAS Republic of Azerbaijan Safarova Z. (Azerbaijan); Associate professor of Economics Vasilenko V.N. (Ukraine), Associate professor of Law Ustimenko V.A. (Ukraine)

News of the National Academy of Sciences of the Republic of Kazakhstan. Series of Social and Humanities. ISSN 2224-5294

Owner: RPA "National Academy of Sciences of the Republic of Kazakhstan" (Almaty)

The certificate of registration of a periodic printed publication in the Committee of information and archives of the Ministry of culture and information of the Republic of Kazakhstan N 10894-Ж, issued 30.04.2010

Periodicity: 6 times a year

Circulation: 500 copies

Editorial address: 28, Shevchenko str., of. 219, 220, Almaty, 050010, tel. 272-13-19, 272-13-18, www:nauka-nanrk.kz / social-human.kz

(C) National Academy of Sciences of the Republic of Kazakhstan, 2018

Address of printing house: ST "Aruna", 75, Muratbayev str, Almaty 
N E W S

OF THE NATIONAL ACADEMY OF SCIENCES OF THE REPUBLIC OF KAZAKHSTAN

SERIES OF SOCIAL AND HUMAN SCIENCES

ISSN 2224-5294

https://doi.org/10.32014/2018.2224-5294.39

Volume 6, Number 322 (2018), 91 - 101

UDC 008, 304.2

A.Y. Baltabayeva, G. Rizakhojayeva

International Kazakh-Turkish University of Hoja Akhmet Yassawi alyona.baltabayeva@ayu.edu.kz, gulnara_rizahodja@mail.ru

\title{
THE PHENOMENON OF THE GREAT SILK ROAD IN THE CULTURAL INTEGRATION PROCESS
}

\begin{abstract}
The consideration of some views about Great Silk Road, which raises the status of the East: "The great Silk Road from two thousand-year histories is the deal of not only great importance with longevity, and also the influence in cultural development of humanity, as the unique cultural phenomenon. Great Silk Road has proved that Europe and Asia, East-West are invented structures. By means of caravan tracks and thanks to the outstanding people such as al-Farabi, Dulati, Yassaui, Balasaguni became known cities as Syganak, Sauran, Taraz, Yassy, Balasagun, Otyrar. On the way of the Great Silk Road it was shown the high level of prosperity and development of a civilization.
\end{abstract}

Key words: Silk Road, Asia, Kazakhstan, Civilization, Culture, East, West.

Intriduction. Since the formation of man one of the waves of the problem is cultural relations and the opinion of other scientists. Many of the theoretical concepts and the idea of international documents related to the origin of human understanding a culture of dialogue and activity, a phenomenon, a situation that looks like postures. Mankind is the only living beings who can determine form of relationships by bringing it to infinity. Thus, it can not be without interview. Even in the ancient culture the communication initiatives of cultures were in a priority. If the past and present cultural-historical process we looked, the form of the two cultures along the friction (in this case, we differentiate between cultures and civilizations are out of consideration) is further evidence of the overwhelming priority was, and still remains: 1) interaction 2) relationship. Interaction of the above isolated from a variety of ethnic and cultural structures of the cultural and historical period is defined as the period of life and it is the most common. Strictly speaking, only by relationships and changes, the culture on the present will live and develop. The present examples of this are the cultural exchanges and civilizing prosperities on the Silk Road.

These principles are very important for Kazakhstan, which is open to cultural and inter-civilizational dialogue. Cultural relations and intertwining of different cultures on the Silk Road is not an archaic phenomenon; at the beginning of the third millennium of a new era all these are still relevant. Future of Kazakhstan is in accordance with the same principle, and that principle is the main theme of national cultural studies.

According to Bakhtin, "A culture is more revealed in the eyes of another culture ..." at the meeting with a different culture reveals its depth: between these two cultures emerging the phenomenon which regulates bias and misunderstanding between them" [1]. Nevertheless, the interaction of cultures in its understanding equalizes not only in an interactive relationship. For example, each of cultural ties of the Great Silk Way of culture, is not only are committed to development that is advantage from each other and through creative synthesis of potential, and also seeks to improve understanding of each other.

Is on the threshold of the twenty-first century, the national culture relevant to the correct answer to the problem of mono-centers and the expansion of globalization in the modern world is the ability to provide capacity-building. Coercion on the part of the globalization of humanity in front of the best values and must produce its own national culture. Not only because of the creative culture of globalization not 
only have the choice of any high aspirations of the strategic and tactical, coordinated and consistent measures to be able to answer.

There are many examples of cultural prosperity in the history of mankind. For example, Philosophy of Fales, History of Herodotus, medicine of Hippocrates, as well as sculpture, lyrics, poetry and many other industries since the beginning of the Mediterranean which was appeared in the proceedings of the Hellenistic civilization. Ancient Hellenistic culture in its development in Asia, Europe and Africa, visited of the three parts of the world that is not only started and completed in Europe. This is the same as in China and Central Asia, the Arab Caliphate and the Byzantine Empire in the Great Silk Road, connecting not only the arteries of trade, as well as the top of poetic creativity of an era, which followed on the heels of its eastern philosophical thought proper development of science and creator of the creative culture of the Great Silk Road of Central Asia forces of about five hundred years to have its own way of evidence.

Research analyzes. Research topic is also linked to government programs that have been adopted in our country. In recent years, the Republic of Kazakhstan in its political, economic and cultural development has become one of the most successful states. The dialogue in the field of contemporary philosophers on the question of national culture are still major problems of philosophy, about this issue are concerned also Kazakh philosophers. Relevance of the topic requires the Kazakh thinkers to review of scientific analysis of the phenomenon of the Great Silk Road. "Cultural Heritage" which was organized with the direct support of the first President of an independent country N.A. Nazarbayev, includes many of the key issues related to the resumption of the old. This proves that our country has reached a possible desire to world civilization. The concept of human development is not a simple tool for people to achieve their personal goals, but on the other hand, it provides an opportunity to focus in the center of the political, social and economic processes. In Kazakhstan, the key paper was prepared in the form of a national report, such as "Kazakhstan - 2030", "Kazakhstan - 2010", which are directed to human development and national, regional and sectoral programs and plan of action, including poverty reduction, education and policy documents aimed at improving the health of the population.

The program "Cultural Heritage", which is carried out with the participation of a wide range of national figures of science, education, culture and literature should be viewed as the beginning of the spiritual revival of the national culture of independence. "In the era of globalization, the world has entered an era of unprecedented opportunities for the development and creation of the world. One more aspect of process of globalization is the aspiration to a world universalization and commitment to the general moral values. However, no matter how developed the process of globalization, no one nation will not give up its historical, religious and cultural uniqueness.

So far, the West and the East, in the minds of many people in Europe and Asia, historically and in terms of geographical location are the opposite of each other. In their view, the West and Europe accounts for a large part of the world that focus on continuous progress and constant improvement, but East and Asia make up the territory of misfortune. In the West it is accepted as an axiom that does not need to prove. They believe that without the developed West would not be civilization and development in the East.

But the Great Silk Road has proved that Europe and Asia, East-West are invented structures. We can never give up the pursuit of the best, to take an example, progress of human civilization, for ourselves esteem, success, happiness is more important than even death, in fact there can be nothing more important than all this, it means that we can confidently say that our region is really valuable space. For people who run this course, gone away and returned to the center of history, nothing will not help.

Determination of the first places of civilization and the theory of its classification is well known to us through the works of well-known scholars such as A.Toynbee, O.Spengler, N.Y.Danilevsky, etc. Civilization does not have clearly defined boundaries and a clear beginning or end. People can identify themselves differently. As a result, over time civilization changes its composition and form. Different cultures interact and gradually change places [2]. We can fully support this idea of S. Hattington. Because, according to the social, economic and political changes in the Middle Ages on the Silk Road due to the rapid development of trade, culture, social ideas, there has been a huge influence for the West and East, Europe and Asia. Along the Great Silk Road was a Muslim renaissance. Oriental culture and philosophy of famous thinkers, their exact science and scientific discoveries have given a picture of civilization. The inherent slowness of the East became even greater after the Renaissance, in this time for the West, which 
is free from religious issues; the eastern discoveries were valuable and endless treasure. They rapidly took all necessary knowledge of Eastern philosophy and created from it their own philosophy. The new philosophy is the philosophy of a new era. Thus, the philosophy of the Renaissance is not obsolete, even this does not match the name. The new philosophy is just an update of ideas Eastern. The objective here is not to oppose the East and West with each other, on the contrary, to protect you from such judgment. Culturologist Zh. Mutalipov said: «You can compare the West with the East, but not the right to oppose them to each other, because the West and the East are the two principles of the world, the two spirits, two bodies, two natural worlds. Therefore, what could be better extension fields of culture, than to curse each other? The main thing we have to remember that the beginning of the culture takes from the East, - [3] In addition, he said about the Great Silk Road, which raises the status of the East: "The great Silk Road from two thousand-year histories differs not only longevity, and also the influence in cultural development of humanity. It is the unique cultural phenomenon [4].

As history shows, intercultural dialogues, in many cases have a positive effect. One example of it is the ancient Greek culture. Unlike other cultures, the ancient Greek culture had a tremendous impact on the rest of the culture. Ancient Greek culture is different with its certain competitive spirit. Polis democracy strongly influences the formation of dialogic thinking. Trade with other countries, the port relationships expanded the cognitive horizons of the ancient Greeks. Ancient Greece has taken the art of writing the Phoenician alphabet, mastered the Chaldean-Babylonian astral world, made of Egyptian art heritage and rich mythology, they admired the ethical ideas of Iran recognized the esoteric wisdom and teachings of the East, and put it all together ancient Greece could be a harbinger of the future of European culture. Not only people, but also the nation's historical memory consists of selecting. Everybody is trying to remember the right and forget their shyness. Therefore, modern European countries do not recognize Muslims as their first teachers. «Euro-centralized we call the totality of the opinion that only the Greek-Roman and their successors Western European culture is considered universal by the relationship of humanity. As a result, they say that cultural influence in the region crossed from west to east and from east to west, but about the impact of the East says is too superficial. In fact, as previously mentioned, the roots of the culture of the Renaissance relate not only to the ancient world, just as it relates to the eastern culture, in particular to the Arab-Muslim culture. Because no one can deny the fact that the Greco-Roman heritage of the West, particularly in the European world of the medieval church of philosophy, were saved thanks to the Arab-Iranian world.

Cultural development is not a feed forward process. In this process, there is always the relationship of old and new, a legacy with others. Cultural identity does not preclude the interaction of cultures and their influence on each other. The cultural space communication is huge. Our region of Central Asia is a zone of interaction of several religions and cultures. One of the main reasons was the passage of the Great Silk Road through this land. The Great Silk Road was actually a dialogue of cultures between East and West, the meeting point of the great religions.

In $\mathrm{V}$ century, Buddhism and Christianity have been included as Nestorianism on the territory of modern Kazakhstan through the Silk Road. Only in VIII-IX centuries, due to the adoption of Islam in Kazakhstan, Nestorianism and Buddhism were ousted. Nothing in life does not pass without a trace, just as all of the past for the development of Kazakhstan affected place of dialogue. Kazakh ethnic group in the light of openness, tolerance and hospitality, as well as the specific characteristics of the oldest religious and moral of the rich heritage do not exceed the results of agreement. Kazakh culture is distinguished by its unique hospitality, no one else like goodwill. Kazakhs always try to maintain harmony and to be diligent relationship with someone engaged in dialogue.

The Great Silk Road is the beginning of cultural relations of the Turkic nomads. He became a caravan, which connects Asia and Europe, the cultural traditions of the west and east civilization and helped to achieve scientific and technological achievements. In this period, due to the fact that most of the Silk Road passed through Central Asia, this region was very famous. Prior to the fifteenth century, the Great Silk Road was the only trade route. At the present stage of the new Eurasian continental bridge, continue on the heels of the Great Silk Road regions of the eastern regions of the Central Asian countries of China, Western Europe was carried out by connecting the transcontinental railway. "Druzhba" and" Alashankou" station interface implemented in September 1990, China and other South East Asian 
countries enabled them to go to Europe via Kazakhstan [5]. Now, thanks to a special cultural policy in Kazakhstan is possible to restore the Great Silk Road.

In general, the earlier the Kazakh science was based on the ancient Eastern, Arab, Iranian, Chinese thinkers, but later due to the strengthening of Russian influence has become closer to European thinking. Peter the first called that Kazakhstan a key to the gates of Asia, and the famous Abay called his land a huge window that extends the understanding between Russia and Europe. Our view of the foregoing arguments that the continuation of historical epochs each other is a historical certainty, and history is the fate of nations, the fate of civilization.

In connection with the radical changes taking place in the world in recent years, it is time for a revalued property, the spiritual riches of the national culture. As a result, it is necessary to put on the agenda the problem of the resumption of the flow of cultures, centuries-old spiritual wealth. Therefore, life itself has shown the need for a categorical rejection of the euro centrist approach to the study of historical, social and cultural processes, it should be noted that this is a prime example of the culture of the Silk Road. Consequently, there is a need to consider the historical development of mankind developed in the relations between civilizations and cultures, explore their relationship in the context of truth. According to the well-known Kazakh philosopher M.Orynbekov: "The contradictions between the West and the East, lead to the recognition of the contradiction between faith and atheism, soul and mind, the revival and heritage, religion and life. It is developing in the epistemological sphere is reflected in the contradictions between education and religion, thought and action, the spiritual sensitivity and cold rationality, wisdom and power, the way of God and the will of the people [6].

But these contradictions are not entirely irreconcilable contradictions. It may seem that the West and the East have not similarities between them. Because, immediately catches the eye the differences between the way of life, traditions, spiritual culture, ideology, and so on.

Western scientists believed that Western society was special with its uniqueness and culture. Thus, for a long time there has been a wrong superiority of the principle that "the West is - the West" and "East is East". But, in our opinion, to date, another principle should be the main: «There is no East without West, and there is no West without East», - because these civilizations and cultures complement each other for centuries and will continue to do so. In conclusion, the evidence of the identity of the cultures of the world to feel the deeper source of three Eastern culture - Chinese-Confucian, Hindu and Buddhist and the ArabMuslim culture of the Great Silk Road, a short insight into the culture of the countries of the Western European countries far from ancient times until today, considering the cultural there was not always a high level of development.

For example, some European scientists attached to its meaning in the Chinese philosophy of Greek philosophy and learned to give a fair price to exceed the high moral system based on the principles of the Chinese government, "scientists considered the country and even oriental method of family management and welfare of the country, which in the example of European countries. They compared Confucius to great Greek thinkers Socrates and Platon. China-based democratic system of education and training is not unnoticed by the Europeans, and some care is carried out by the state (for example, in times of natural disasters was a temporary cessation of the payment of taxes, the state grain reserves, organization, etc.). Europeans recognize the knowledge management of Chinese emperors and put them in the example of European monarchs. On this situation, one Western scholar wrote: «Eastern countries, including China's vast empire, with the difference between the philosophies of the West, headed by the so-called knowledge and talented people, according to the principle of Plato, China - country of philosophers." [7].

Of course, the phenomenon of civilization in the world depends on its wide range of channels. In this regard, the culture A.J. Toynbee is widespread in the mainstream of Western historians, referring to the unity of the concept of comprehensive analysis of Civilizations, he said:"The concept of the unity of cultures - to go to a false concept» [8].

How can we interpret this widespread opinion among Western historians? In fact, no one can deny that in our time, Western civilization has its own wide-spread economic impact worldwide. Along with the economic unification political unification deepens its roots. As a result of economic and political expansion of the West, many countries (not only in Western countries) have become members of one of the world system, which are subject to a uniform international law in different countries. 
At the same time, Western civilization does not just hold humanity in its economic cell. Western scientists overestimate this historical phenomenon. They believe that, at the present stage, the process of unification of the West on the basis of the economic model of the world is coming to an end, so that this phenomenon should be fully carried out in other directions. But, in this case, which seems to be of the receipt of a mix up their cooperation in the Unification as if it is a problem which is just emerging historical facts before reaching delve in high level.

First, what happens if we look at the world only from the political and economic point of time, at the same time forgetting about the culture? How can we explain such incorrect view of Western scholars? For ensuring reliability of the historical truth, we will try to analyze sense of the English word "natives". Europeans consider them as soon as one part of an animal and flora. Respectively, as it is possible to explain such barbarity of Europeans on the relation of living people?

In this regard, it should be noted the problem of "Eurasian culture," and because the topic along with the problem of "East-West" has not yet found its solution. Both of these problems are closely linked, and the Great Silk Road is one of the first examples.

For historical reality let's just focus on the theme "Eastern culture". Eastern culture is unique for its beauty and originality of medieval Baghdad, peculiar to themselves various celebrations of ancient China, unimaginable mystical rites of Indian yogis and cosmological mysteries of Tibet, Sharia law and wonderful tales of Scheherazade, the principles of the world famous teacher Confucius, etc. In this case, is it possible to doubt the spirituality of Eastern culture? Unfortunately, any of the cultures of the East and the West in the mists of time to the establishment and to this day it permanent, does not know that there are legal and cultural relations. In fact, the deeper into the history of world culture, known to natural harmony and similarities between cultures, and can still be seen in their mutual relations conflicts.

According to scientists, Europeans are not true successors of the Hellenistic civilization. According to historical reality, the ancient Greek philosophy and science by European Muslims have Arabic translations. This means that they were not able to get to know the culture of other countries and even of their country without philosophers of the medieval East. For example, all of the European Jewish philosophy was based on the works of Spinoza, Maimonides, Saladin, and the poetic images of the great characters of Dante was taken from the great philosopher Ibn Arabi Mukhiddin, writers-humanists of the European Renaissance is widely used artistic techniques of Arab and Iranian classics, even the word "humanism" Saadi used the first before the appearance of Renaissance.

Representatives of modern Western comparativism (science dealing with comparing languages in order to establish their relationship, their genetic classification), including their classic F. Nortrop, in 1947 proposed the idea of the focus of the West and the East. If the in-depth look at this idea, you will notice that Western civilization wants to recover through the culture of the East. Certainly it is possible to agree with this opinion or ignore it, but here the problem is not to elevate one culture or to belittle another. The problem in the development of world cultures through international dialogue and equal relationship.

"West" and "East" cultural pole opposite each other in most cases, two cultural traditions of the two forms of spirituality. If it is so, these ideologies, language and cultural approach to the world of two types of systems are different. This is reflected not only in the broad areas of humanitarian traditions and views in the field of culture (philosophy, ethics, aesthetics, politics, etc.), but also in the way of life of the peoples of the world and different cultural values and welfare.

As for the truth, none of the European countries, born of religious orientation, or spiritual teachings that do not exist in the East (Asia), not caused by religions and their teachings have been involved in adapting to change. All the great spiritual teachings of humanity spread from Asia. Namely, Brahmanism and Buddhism in India, Judaism, Christianity and religion in the Middle East, Confucian and Taoist religions in China, and the Islamic religion in the Arab countries formed. Sufis large Idris Shah said in this regard, the following comments: "Our religion, which we claim are mainly a natural mixture of Christian, Jewish and Islam [9] (eg Spain).

In this regard, well-known scientist AJ Toynbee said: "What is civilization that has lost its cultural development, internal forces, begins to absorb other social structures [8, p. 356]. In fact, under the influence of other cultures to the cultural influence of foreign economic or political model of civilization is much more useful and effective. 
Along with a variety of civilizations there is something that unites humanity. This is primarily based on the integrity of the world - the "universal culture". Integrity of the world is a world production in the world and the world's problems through the development of various countries and peoples. The integrity of the world is the basis for the common prosperity of human culture in the modern world. This means that "the fate of contemporary culture" that unites humanity, is directly connected with human spiritual values, humanism and the revival of protection of human rights, the development of scientific knowledge and advanced technology, the continuity of the national culture, the environment and social life.

Universal culture, art and poetry, science, the production of the most advanced types of different peoples and descendants of the centuries-old way of life in the truth and knowledge about the unique ways. Human race, class and racial hatred are on the basis of those principles, which prevent people and without prejudice to the right of the people, free from poverty and cultural colonialism in the creation of a single civilized direction. Samples of the culture of today become the main goal, which is the main factor in the formation of a single human culture. Over time, the different cultures of the peoples of cultural relations and ties between the channel has been expanded, and cultural changes that have occurred in the wizard and its impact on others. Global cultural integrity prevalence of certain cultural achievements in the world is growing. So, we have a new stage of development in the world of human values.

There is a search of new ways of development and formation of spiritual orientation in the modern world. It is search culture of the world, harmony and dialogue is the most effective and perspective way. Goethe at the end of his life told that everyone sane person has to be a liberal. He meant that if the person considers him sane, he has to be patient and peaceful [20].

The background of the new ideological orientation is already being developed and the rationale for their atmosphere of public opinion is an indicator of our moral responsibility. Great Silk Road, which is not only a touch of the East and the West, as well as common one is an example of the realization of the idea of a culture of dialogue. Not only in the Middle Ages, the modern world is very different to each other on interviews with cultural traditions into the relationship. At the same time, the community of people with a variety of new types of information that appears on the storage and distribution of human history is a good fit for us. All of the above-mentioned negative aspects of the processes associated with the attractive aspects of technology. The mankind has to get used to dialogue. Therefore, it is necessary to refuse all evropo-, American-, Africa-centrism and to absolutize own culture and values.

According to A. Kulsariyeva who profoundly was engaged in studying of the matter, "Dialogue" is white a flag of our time because lately it is very widely used. About it it is audible in political programs, scientific works, discussions by training etc. Especially in the modern unstable world peaceful dialogue is the reason of avoidance of the different conflicts.

Before our eyes, there is a change of a paradigm of the general cultural world is; it is possible to tell some kind of "conceptual revolution". Its value is outside understanding traditional and modern, in connection with formation of the new principle of dialogue.

What is the dialogue? On A. Kulsariyeva's explanation, dialogue takes word roots from Greek "dialego" - conversation of two people. On old explanations dialogue means an exchange of opinions or joint acceptance the decision..

Today, its meaning has expanded considerably. Due to the wide interpretation of the dialogue, it is considered a form of human culture. In addition, the entry into linguistic terms, which go beyond linguistic heuristic concept means an abundance of power [10].

The most important feature of dialogue is the good reason for mutual understanding. Relationship true human value. According to M. Bakhtin, All human nature (internal and external) consists from relationship. Life - means to be in the relations. The person reveals only in the contacted life, that is reveals in collaboration with other people [11].

Dialogue is the root of all human relationships. The idea of dialogue - this is a meeting of two different types of ideas, the idea of two different cultural worlds. Every culture is a separate world, they can not fully assimilate with each other, because every culture has its "original distribution." So the dialogue is possible only when the two sides have important views and the right attitude.

New dialogue discursive approach of the Humanities is connected with scientific heritage of $\mathrm{M}$. Bakhtin (1895-1975). And it in turn, the phenomenon which prepared on the basis of "dialogue philosophy" in the directions of a hermeneutics of C. Levitte, F. Rosenzweig, F. Ebner, M. Buber. 
At present, the Dialogue has been developing in two directions: the formation of a true pluralism, to ensure the equality of the different forms of culture and the creation of a universal global anti-totalitarian culture [10].

Modern civilization of the future must be characterized as a global condition. In other words, the "third world" countries are poor, but the information can not agree to a long time in the conditions of the inhabitants of the relatives of the rich and the rich more rich and the poor, which is trying to create more of the poor of the world order. At the same time, the number of developed countries, the average monthly salary is insufficient to persons of the age of many of the post-socialist countries. President of the Republic of Kazakhstan said an interesting opinion about this theory: modern progress of "Westernization", as well as the compromise does not mean the victory of the whole world. The whole world of Liberal stigmatisms Western European and North American civilization model is unique and invaluable experience with its numerous individuals in the random fluctuations and not in favor of history and experience, as well as a certain period of time is understood as a model "[12].

In the 20th century formation and development of cultural science was bilateral: aspiration ethno cultures to self-identification and prosperity of the cultural center common to all mankind.

And cultural integrity as one way of addressing the imbalance between globalization presented the concept of sustainable development in the modern world. Supported by the United Nations on the eve of the three-thousand-year "global transformation" project was presented. In this document, "capitalism won a historic victory" instead of the euphoria that is based on the selfish interests of western civilization was in need of the feeling of limitedness: "The world of poverty, splendor and contradictions is approaching the new millennium; enormous wealth - spiritual and material - did not make us happy, for the deep foundation of earthly relationships continues to be flawed - greed - the root cause of all the troubles, driven by the best minds to unprecedented excellence. Mankind ancient times to survive were forced to engage in any form of hoarding, and not disdaining the means to achieve. Now features allow you to do without unnecessary hoarding, it lost the original meaning.

The history now at the crossroads, is necessary to it: continuation is spontaneous - the evolutionary movement in uncertainty, with all surprises, sophisticated variations: "confrontations, races of arms, spheres of influence, a hegemonies, etc., or historical turn to century dreams of people that can occur during an era of the far-sighted heads who realized is a people at large, by transformation of the become obsolete terrestrial relations to the humane, fair world" [13].

UNESCO announced a new program "Culture of peace", as the main value of the new civilization. Consider this situation prerequisites for sustainable development, UNESCO adopted in Paris in 1998, the Declaration of "Stable Development" considers important the following conditions:

- Completely it is necessary to consider former concepts of economic development, priorities of the current culture of the world are social development, fight against poverty and social justice;

- should be gradually decreased in numbers the economic disparities between countries, for that no country should be left behind by development, it is necessary to increase the share of the least economically developed countries;

- all social groups should participate fully in the implementation of development, it is necessary to deepen the dialogue of governmental and non-governmental organizations involved in the culture of peace;

- for the formation of a stable social environment should be paid great attention to the internal causes and origins of conflict and in post-conflict situations need to pay more attention to measures to avoid this crisis again;

- Corruption remains too weak as a result of the prevalence of each type of sustainable development in developing countries, including in the new independent states of the historical experience of one of the main causes of poverty shows the corruption of the authorities;

- paradigm of development of the prevention and management of crises in the human development index, the equality of men and women, must contribute to poverty reduction and economic issues;

- Implementation of the above conditions will increase the activity of the poor, strengthen social justice" [14].

All information about the value of a single human in the history of the ancient culture ("the Epic of Gilgamesh", "Avesta", the Greek philosophers of the world's religions, the new humanists of the time) felt 
in the whole historical process of humanity opened himself only as a subject of the XX century. Before the start of the process of westernization of the world (the great geographical discoveries, colonies, cultural and axiological expansion, etc.) is one of the traditional cultures of the world, one of the few concepts were, and are, as a rule, "we" - "they" are based on binary opposition. "We" is not a "real" people, "they" and "premature" and "we" and "civilized" and "they" are "wild". Other human "civilization" is not, "premature" and that are not clean or dirty and had a bad smell coming from inside and hid after went out into a crime of aggression. It is not merely the same periods, as well as there are current and inter-ethnic conflicts in the Balkans, Afghanistan, Africa, etc. [15].

The "we" and "they" division, based on the "culture" of discrimination is not only in everyday life, including on the basis of "research". Description by European ethnographer Indians: "The Mata-Grosté, I saw a group of Indians of all accidents, eight people, including one suffering from syphilis, another injured shoulder, and the third was an open wound, and one of them had the disease scaly skin. Nambikvary dressed only when they were allowed to missionaries. The smell of rotten meat and fish merged with their skin. " "... They do not eat meat, there is no justice for them, they are naked, they eat raw scorpions, worms and beetles" [16]. People hated each other; there is the question of the historical roots. Mostly, they are due to a variety of cultural traditions, ethnic and cultural foundations of mental cognitive interest, but without causing problems, they are the basis for the analysis of the socio-cultural. Thus, ethnographic and anthropological studies and descriptions of the ethno-cultural differences and differences in the first place, it will be highlighting the universal values of cultural consciousness of mankind as a whole.

Most importantly, the new recognition of the truth: the vital processes of the universal nature of the cultural interaction between the regions and the unity of the mutual dependence of modern humanity's destiny, so to speak, and the beginning of civilization as well as the implications of the realities. Some nations, not just the fate of the European Community, covering all common in various areas, "disasters" are defined: the world wars, totalitarian regimes, the Nazi expansion, international terrorism, economic stagnation, environmental stress, etc. All of these processes is not just limited to the other, without prejudice to the position of the edge of the cultural development of the people could not be held.

Western modern classic, futurologist Alvin Toffler, analyzing the great changes that are expected said: "modern society is the real wealth of knowledge and power, has become a concern. The Company's rapid transformation of the body, as the world communist and capitalist, was divided into North and South has disappeared. Instead, the economy is growing fast and slow systems. If the first is based on the idea of innovation and renovation unique, then the second is based on the development of their tradition, stable and inert. A new culture of human knowledge and the ability of the world are based on the ideology and self-development of creative freedom [17].

Studies the history of civilization, historiography as part of a higher synthesis section, a new kind of civiliography parts can be viewed as a scientific discipline. It is part of the historical sciences is based on the results of the studies and other scientific subjects. Civiliography questions can be viewed in two ways; First, the interaction of macro-theory logic determines the degree of development of the civilization, and secondly, the development of the identified macro-theoretical approach to the issue will be discussed. Civiliography, the actual facts and conclusions is based on the target to study the structure and procedure of the macro-theory.

At this point, civilization genetic, functional and transformational structure must be able to distinguish from each other, because the latter can be one of the genetic structures of civilization. Genetic and functional structure of live opposite each other, because it will be the end of a long process of becoming more organized civilization. The first genetic components of the service do not have to be in the lead role. Each layer structures is hard to not only maintain its special place in the system reached its genetic and functional area. After that, in accordance with the process of regional structure does not correspond to the formation of a civilization. Genetic structure of civilization is part of the service layer and on the other hand, the service layer is formed into the genetic structure of civilization. Civilization and within the same regional structural components, such as the one it replaces, and the results of its own development, not only to increase the quality of the influence of structures belonging to the same line [18].

According to Mircea Eliade, who is the principal researcher of myths of religion, the very first religious beliefs and holy appeared in these steppes [19]. For the Europeans, who grew up on the books 
Eliade our prairie lands seem to be something unreachable. When they come to us, first of all they asked to show the steppe. We, Kazakhs, do not appreciate these beauties of our steppe world. In our time the Kazakhs do not want to live in the wilderness, they increasingly prefer to live in the city. In this regard, what can we do? Our country is civilized, for development of our country we have to address to sources and create the correct spiritual condition of the people. Respectively, then we will have a youth which will be modern and developing, but at the same time spiritually developed.

Kazakhstan, involved in the global orbit of search of a universal model of multinational and multireligious interaction, became the author of its own model of tolerant and harmonious society recognized in the world community and the country has laid the foundation of further improvement of public relations on the basis of civil peace and harmony [20].

People always sought to leave the closed world. In Scandinavia the person who didn't leave the house was equated to silly people. Vikings by the ships subdued oceans, the dealers striving for benefit visited the whole world before the Great geographical openings.

Merchants who went from the country of Francs to China learned Arab, Persian, Chinese. To be protected in other countries they united in guild.

And in the truth merchants included the whole world in the movement.

On the European holidays the Syrian sounds were audible. In Marseille the Egyptian papyruses, and in Arles - a thing from an ivory were on sale.

All trade was in hands of Venetians and geneses. Such vital style occurred during culture of the Great Silk Road.

Conclusion. Ambivalent culture as a way of human life is uncertain. The cultural dialogue and exchange of artifacts, share, and serves as a universal interest in the concession. Deepening and the increasing complexity of processes of history in the second orientation will increasingly become a priority. It is only in modern globalization, such as Total, without exception are off, including Genuine Brand and harmonious cultural transitions can be found out in the form of a meta-structures. That the realization of such culture of civilizations dialogue in the history of the Great Silk Road is the structure of the phenomenon.

Great Silk Road, to switch to a higher society with diverse ethnic and cultural structures showed that the best stand-alone. In a strict sense, the end of the interaction of uniform structures, that is, there are private organizations that regression. This is where the end of each uniform structure, complexity and the level of developed countries they live in, and others to contribute to its own definitions, those who have any impact on the affected will be tested. The most complex in terms of its organization is "Stand-alone structure itself to meet even the most basic phenomenon will interact with it. However, the cultural phenomenon that has never been influenced the other substances in the image, so that it is not worthy of its own, but there is no feature of its own.

Historical equivalents of the culture of the Silk Road will go to the Greek Viking blood, relations of the Mediterranean basin, China and India sites to link East and West Asia and the connecting junctions, etc. But only at the level of the versatility of the Great Silk Road was a rise in the level of meta-culture. This phenomenon of prototypes in the Middle East and Central Asia with China, precious stones and precious metals, crafts and exotic goods, cultural artifacts to the direction of the exchange of communications. Great Silk Road culture of a full-fledged operation of the VI-IX centuries coincide with the period of China to the west of the international monetary and silk transported back into the nature of the spiritual teachings of world religions, arts and crafts began to spread. A high level of civilization is along the Silk Road culture of the city.

The great Silk Road is the proof of that in the conditions of dialogue and a cultural exchange the nomadic culture rose by high level. The main deposits of Kazakhs to a world civilization are: a) the first in the history of mankind the Eurasians nomads could master space (use of horses about which K. Jaspers spoke); b) nomads could expand environment, they harmoniously mastered both deserts and the steppe earth; c) the Eurasian nomads are catalysts of history (A. Weber), they became the reason of a new civilization (India, Iran; country Huns, Arab caliphate, etc.); d) By means of the Great Silk Road and other cultural and communication systems former Turks played an intermediary role between the East and the West, they became the reason of their dialogue; e) Kazakhs the first introduced such artifacts as, trousers, a saber, a yurts, the carriage, metal processing, jeweler art, construction; g) universal system of outlook of 
Turks Tengrism to a human form of importance of cooperation and coordination; h) a position of Kazakhs "Be the person!", to look at mood of others, to be in understanding with other people, to respect seniors and children have a huge role in the modern world [21].

One more lesson of the Great Silk Road in recognition of high level of Muslim culture. As the academician A. Nyssanbayev noted, that with VIII an eyelid till the XVIII century the Islamic culture couldn't achieve such high growth rates without contribution of cultures of such cities as Baghdad, Bukhara, Samarkand, Herat, Ray, Isfahan, Shiraz and Tabriz. In these cities in the form of Islam the craft and art, science and literature, architecture and calligraphy especially prospered. The great Silk Road connects among them Europe, the Central East, Central Asia, China and Caliphate. Therefore it was the intermediary between Europe and Asia. Thanks to the Great Silk Road the Kazakh steppe as its geographical position was the cause of trade and cultural influence of the West and East. Silk and paper from China to the Mediterranean Sea through Iran, India with gold and spices, horses and skins were sent to Central Asia. Caravans loaded with goods through the territory of Kazakhstan, there was a nomadic herders and ties in the exchange of cultural values. By means of caravan tracks and thanks to the outstanding people such as al-Farabi, Dulati, Yassaui, Balasaguni became known cities as Syganak, Sauran, Taraz, Yassy, Balasagun, Otyrar [22]. On the way of the Great Silk Road it was shown the high level of prosperity and development of a civilization.

\section{REFERENCES}

[1] Bachtin M. Otvet na vopros redaktsii "Novogo mira". Moscow: Bachtin. v 7-I t. Isskustvo Press, 2002.

[2] Khantington S. Stolknoveniye tsivilizatsiy.Moscow: Izdatelstvo AST Press, 2003.

[3] Mutalipov Zh. Madeni dialog zhane orkenietter togysy. Almaty: Raritet, 2002.

[4] Mutalipov Zh. Kazak orkenietinin kainar bastaulary. Adam alemi Publications. 2002. №3. P.56- 60 .

[5] Garifolla Esim. Ulttyk orkeniet zhane madeni bagdar. Kazakhstan: syndarly zhyldar zhane galamdyk maseleler. KR prezidenti N.A. Nazarbayevtyn «Syndarly on zhyl enbegi» boiynsha otkizilgen korytyndy gylymi-praktikalyk konferentsiya materialdary. Almaty: Kazakh University, 2003. p.338.

[6] Orynbekov. Ezhelgi kazaktyn dunietanymy. Almaty: Gylym Press, 1996.

[7] West and East. Tradition and modernity. Moscow: Science, 1993. 403 p.

[8] Toynbi A.J. Postizheniye istorii. Moskva: Politizdat Press, 1991.

[9] Idris Shakh. Sufizm. Moscow: Mysl Press, 1994.

[10] Kulsarieva A.T. Madenietter men dinder arasyndagy sukhbat. Beybit madenieti zholynda. Almaty: KazMU UNESKO, 2000. P.199-207.

[11] Bakhtin M.M. Esthetics of verbal creativity. M.: Art, 1979. 423 p.

[12] Nazarbayev N.A. Gasyrlar togysynda. Almaty: Oner Press, 1996.

[13] UN Project for the Third Thousand Anniversary, Transformatsiya mira. Almaty: Missiya UNESKO, 1985.

[14] Gabitov T. Kh. and Nurzhanov B.G Ornykty damu. Beibit madeniet zholynda.Almaty: KazMU, 2000.

[15] Gabitov T., Mutalipov Zh. etc. Kulturologiya. Almaty: Raritet, 2001.

[16] Etnograficheskiye issledovaniya na Zapade. Tomsk: Universitet, 1996.

[17] Toffler E. Tretiya volna. Moscow: AST Press, 1999.

[18] Kenzhetay D. Dasturli turkilik dunietanym zhane onyn mani. Ezhelgi koshpeliler dunietanymy. Astana: Audarma Press, 2005.

[19] Eliade M., Joan P.Couliano. Dinler Tarihi. Ali Erbas. İnsan Yayınları. İst-1997.

[20] Dairabayeva G.B., Maldybek A.Zh. Turkic world and Kazakhstani model of interreligious and interethnic tolerance. News of the national academy of sciences of the republic of Kazakhstan. Series of social and human sciences. Almaty, NAS RK. ISSN 2224-5294. Volume 4, Number 320 (2018), P. 68 - 75. https://doi.org/10.32014/2018. 2224-5294

[21]Orkeniet.Kazakhstan. Ulttyk entsiklopediya. Almaty: Kazakh Encyclopaedia, 2005.

[22] Nysanbayev A.N. Al-Farabi turki, kazak, iran madenietterinin kosushy buyny retinde. Kazak khalkynyn filosofiyalyk murasy. V. 16. Farabitanu. Astana: Audarma Press, 2006. 
А.Ю. Балтабаева, Г. Ризаходжаева

Международный казахско-турецкий университет имени Ходжи Ахмеда Ясави

\section{ФЕНОМЕН ВЕЛИКОГО ШЕЛКОВОГО ПУТИ В ПРОЦЕССЕ КУЛЬТУРНОЙ ИНТЕГРАЦИИ}

Аннотация. В данной статье рассматривается неоспаримая значимость Великого Шелкового Пути, которая в свою очередь возвысила статус Востока: «Великий Шелковый Путь с двухтысячилетней историей это не только многовековое явление с большим значением, но и также влияние в культурном развитии человечества, как уникального культурного феномена. Великий шелковый путь доказал, что Европа и Азия, Восток-Запад - это созданные им структуры. С помощью караванных путей и благодаря выдающимся людям, такими как аль-Фараби, Дулати, Яссауи, Баласагуни, стали известны города Сиганак, Сауран, Тараз, Яссы, Баласагун, Отырар. На пути Великого Шелкового пути проявился высокий уровень процветания и развития цивилизации.

Ключевые слова: Шелковый путь, Азия, Казахстан, цивилизация, культура, Восток, Запад.

\section{А.Ю. Балтабаева, Г. Ризаходжаева}

Қожа Ахмет Ясауи атындағы Халықаралық қазақ-түрік университеті

\section{МӘДЕНИ ИНТЕГРАЦИЯ ҮДЕРІСІНДЕГІ ЖІБЕК ЖОЛЫНЫН ФЕНОМЕНІ}

Аннотация. Бұл мақалада Шығыстың мәртебесін жоғарылататын Ұлы Жібек Жолының маңыздылығы талқыланады: «Екі мың жылдық тарихы бар Ұлы Жібек жолы - бұл өте маңызды көп ғасырлық құбылыс ғана емес, сонымен қатар бұл адамзаттың мәдени дамуындағы ерекше мәдени құбылыс ретінде қарастырылады. Ұлы Жібек Жолы Еуропа мен Азияның, Шығыс пен Батыстың құрылымын жасатқан дәлел болып табылады. Керуендер жүрген бағыттарының көмегімен және Әл-Фараби, Дулати, Яссауи, Баласағұни секілді ұлы даналардың арқасында, Сығанақ, Сауран, Тараз, Яссы, Баласағұн, Отырар сияқты көне қалалар белгілі болды. Ұлы Жібек Жолы торабында өркениеттің дамуы мен гүлденуінің жоғары деңгейі анық көрінді.

Түйін сөздер: Жібек Жолы, Азия, Қазақстан, өркениет, мәдениет, Шығыс, Батыс.

Information about authors:

Baltabayeva Alena Alaskite - associate Professor, candidate of philosophical Sciences, Director of the Department of science of the University Ahmet Yassaui, alyona.baltabayeva@ayu.edu.kz;

Gulnara Isakhojaeva - PhD, faculty of Philology, gulnara_rizahodja@mail.ru 


\section{МАЗМҰНЫ}

Беспаева Р.С., Бугубаева Р.О., Мануэль Ф. Грела2. Көрсеткіштердің теңдестірілген жүйесі негізінде Щучинск-Бурабай курорттық аймағын дамытудың кешенді стратегиясын қалыптастыру ................................................................................ 5

Аюпова 3.К., Құсайынов Д.Ө.Азаматтық процесстерді жетілдірудегі интеграцияның кейбір қырлары...................... 13

Құсайынова А. А., Вальдемар Козловски, Геращенко И. П.Қазақстан республикасындағы міндетті әлеуметтік сақтандырудың қаржылық-құқықтық тетіктерінің ерекшеліктері.

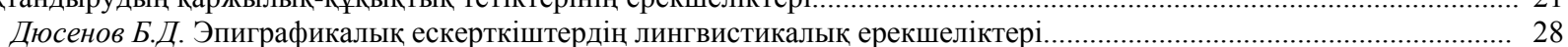

Джумадилова Ш.Г., Атабай Б.Ж. Қазақстандағы халықтың жинақтарының динамикасы......................................... 33

Карабалина А.А., Альситова А. Б., Кереймаганбетова Ж.Н., Абишева Н. М. Құндылық - рухани-адамгершілік

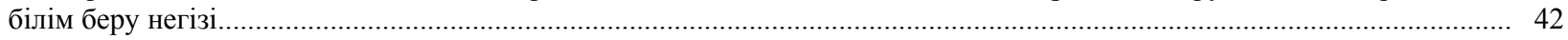

Кенжебаева Д.К., Өрмөрза Б. Ғ., Дашгин Махаммадли. Қазақстандық заманауи жастардың құндылығы............. 51

Нурманова А.Ш., Медерова Д.Е., Дюсенов Б.Д. «Бөкейхан әулетінің талдыбейіт қорымы» эпиграфикалық ескерткіштері тарихи дереккөз ретінде.

Кыдырова Ж.Ш., Онласынов Е.З., Абишова А.У., Шадиева А.А. Оңтүстік Қазақстан облысы сүт және сүт өнімдері нарығындағы жағдайды зерттеу ......

Абимова Г.У., Аманжолов Р., Мынбаева Б.Н., Ибрагимова Д.И. ЖОО-да биолог-студенттердің жобаларды

ұйымдастырылуы мен орындалуына даярлығы.......

Балтабаева А.Ю., Ризаходжаева Г. Мәдени интеграция үдерісіндегі жібек жолының феномені............................... 9

Бурганова Р.И., Абдугалина С.Е., Туякова А.Е. Студенттерге бағытталған білім беру арқылы білім сапасын

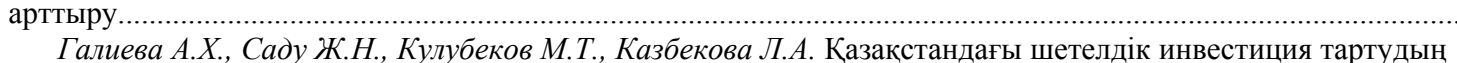

институционалдық жағдайын (талаптарын) бағалау..

Джалилов 3.Г., Батырхан Б.Ш. ХX ғ. екінші жартысындағы шетелдік исламтанушылардың ислам және саясат

туралы теориялық дискурсы.......

Джумабекова А.Т., Канатова А.Ж. Қаржылық ынтымақтастық жағдайларындағы Қазақстан республикасының

ұлттық банкінің өткізу механизмінің өзгеруі......

Дүйсен Г. М., Айтжанова Д. А. Қазақстан және Орталық Азия елдеріндегі көші-қон процесстері дамуының мәселелері мен ерекшеліктері

Есендұлова М.Н. Қазақстандағы « Қиын балаларды» оңалтудың және әлеуметтендірудің психологиялық ерекшеліктері

Жакишева К.М., Жуманова Д.Т., Мукашева Г.М. Экономиканың аграрлық секторының тұрақты дамуына арналған ауыл шаруашылық кәсіпорындарының қаржылық шарттарын мониторингінің рөлі.....

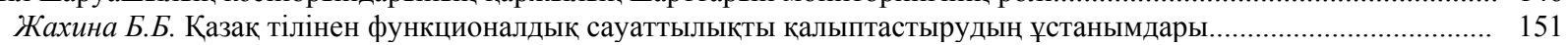

Идресова У.Х., Садуахасова 3.Ж., Муханова А.Т. Криминалистика....................................................................... 156

Савельева В. В. Қазақстандағы кредит технологиясын пайдалану және дамуының тарихи және педагогикалық базасы.

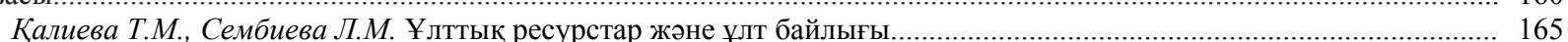

Каримова Р.У., Хаджиева Г.У. ҚХР Ұлттық саясаты контексіндегі ШҰАА-ның этносаяси және әлеуметтікэкономикалық трансформациясы мәселесі.

Керімбек Г., Молдашбаева Л., Джрауова Қ., Ажмухамедова А., Мизанова А. Қазақстан республикасының

республикалық бюджетіне түсетін салық түсімдерінің көрсеткіштерін талдау және бағалау.....

Жолдасбекова С.А., Парманкулова П.Ж., Асаналиев М.К. Мүмкіндігі шектеулі балаларды дамытудағы ұлттық ойындар

Молдакенова Е.К., Байгабулова К.К., Онаева Б.Т. БҚО-да инновациялық үрдістерді басқарудың аймақтық

аспектілігі жүйесінің дамудың жолдары.

Мұратова Г.К., Шаушенова А.Г., Жумасеитова С.Д., Онұварбаева М.Б.Білім беру үрдісінде бұлттық

технологияларын қолдану......

Несіпбеков E. Н., Аппакова Г.Н. Кәсіпорынның инвестициялық портфелін қалыптастырудың теориялық

Нургабылов М.Н., Барлыков Е.К., Егембердиева С.М. ҚР есеп өнеркәсібінің дамуының басқаруының трендсі....... 220

Нурымбетов Т.Я., Абишова А.У., Уразбаева Г.Ж., Кыдырова Ж.Ш., Байнеева П.Т., Абишо Н.У. Модернизациялық

жағдайындағы қр халқын әлеуметтік қолдауының басымдықтары.....

Рахимова С. А., Тургумбекова М. М. Қазақстан республикасындағы шағын және орта бизнестіңмемлекеттік қолдау

бағдарламалары және олардың тиімділігін жүзеге асыру шаралары.......................................................................... 233

Руденко Е.И. Орталық пен Оңтүстік Азия мемлекеттері арасындағы ұғынудың бұрмалануы - «Жұмсақ күш»

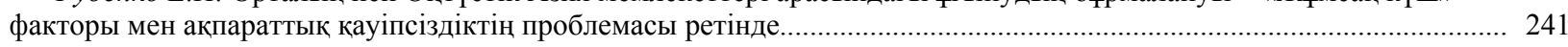

Тохтабаева Ш. Қазына-сандық.......................................................................................................... 251

Утепкалиева К.М., Сабирова Р.К., Кенбаева Г.У. Мұнай-газ секторындағы мемлекеттік-жеке серіктестікті дамыту

Мыңбаев Д. Е. Банкте басқару есебін ұйымдастыру тұжырымдамасы...

Султанова Г.С. Жаңа формацияның экономисі - бакалаврдың кәсіби құзыреттілігін қалыптастырудың

Шаяхметова А.А. Университет жағдайында инклюзивті білім беру үшін педагогтарды оқыту....... 


\section{СОДЕРЖАНИЕ}

Беспаева Р.С., Бугубаев Р.О., Мануэль Ф. Грела. Формирование комплексной стратегии развития ЩучинскоБоровской курортной зоны на основе сбалансированной системы показателей. Аюпова 3.К., Кусаинов Д.У., Уинстон Наган. Некоторые грани интеграции в совершенствовании гражданского процесса.

Кусаинова А.А., Козловски Вальдемар, Геращенко И.П. Обзор некоторых особенностей финансово-правового механизма обязательного социального страхования в республике Казахстан......

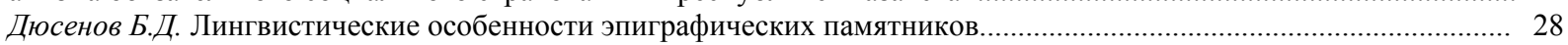

Джумадилова Ш.Г., Атабай Б.Ж.Динамика сбережений населения в Казахстане................................................... 33

Карабалина А.А., Альситова А. Б., Кереймаганбетова Ж.Н., Абишева Н. М. Ценность как базовая основа духовнонравственного образования.

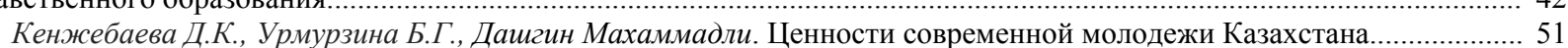

Нурманова А.Ш., Медерова Д.Е., Дюсенов Б.Д. Эпиграфические памятники «Некрополи талдыбейит династии

Бокейхановых» как исторический источник.

Кыдырова Ж.Ш., Онласынов Е.З., Абишова А.У., Шадиева А.А.Исследование ситуации на рынке молока и молочной продукции южно-казахстанской области

Абишова Г.У., Аманжолов Р., Мынбаева Б.Н., Ибрагимова Д.И. Готовность студентов-биологов к организации

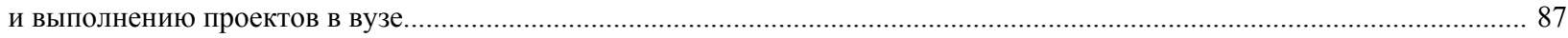

Балтабаева А.Ю., Ризаходжаева Г. Феномен великого шелкового пути в процессе культурной интеграции............... 91

Бурганова Р.И., Абдугалина С.Е., Туякова А.Е. Повышение качества образования посредством

студентоцентрированного обучения...

Галиева А.Х., Саду Ж.Н., Кулубеков М.Т., Казбекова Л.А. Оценка институциональных условий привлечения

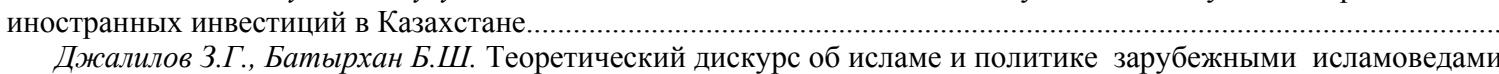
второй половины ХX в.

Джумабекова А.Т., Канатова А.Ж. Трансформация трансмиссионного механизма национального банка республики

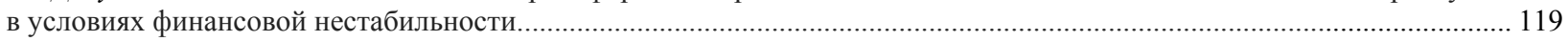

Дуйсен Г.М., Айтжанова Д.А. Проблемы и особенности развития миграционных процессов в Казахстане

и странах Центральной Азии.

Есенгулова М.Н. Психологические особенности реабилитации и социализации "Трудных подростков"

в Казахстане".

Жакишева К.М., Жуманова Д.Т., Мукашева Г.М.Роль мониторинга финансового состояния сельскохозяйственных

предприятий в обеспечении устойчивого развития аграрного сектора экономики.........................................................146

Жахина Б.Б. Принципы формирования функциональной грамотности казахского языка.......................................... 151

Идресова У.Х., Садуахасова 3.Ж., Муханова А.Т. Криминалистика......................................................................... 156

Савельева B.B. Исторические и педагогические основы формирования и разработки кредитной технологии

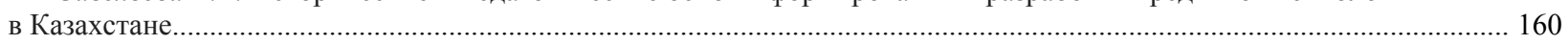

Калиева Т.М., Сембиева Л.М. Национальные ресурсы и богатство нации.................................................. 165

Каримова Р.У., Хаджиева Г.У. К вопросу об этно-политической и социально-экономической трансформации

СУАР в контексте национальной политики КНР

Керимбек Г., Молдашбаева Л., Джрауова Қ., Ажмухамедова А., Мизанова А. Анализ и оценка показателей

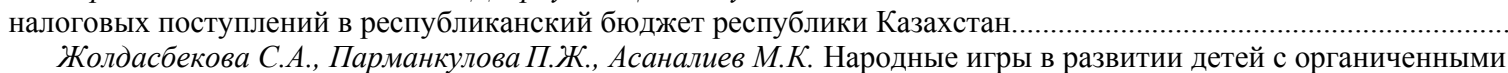

Жолдасбекова С.А., Парманкулова П.Ж., Асаналиев М.К. Народные игры в развитии детей с органиченными

Молдакенова Е.К., Байгабулова К.К., Онаева Б.Т.Пути развития системы регионального аспекта управления

инновационными процессами в АПК.

Муратова Г.К., Шаушенова А.Г., Жумасеитова С.Д., Онгарбаева М.Б. Применение облачных технологий

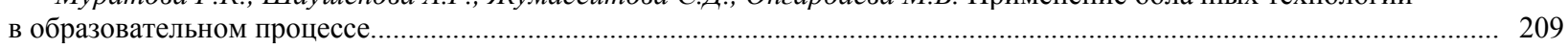

Несипбеков Е.Н., Аппакова Г.Н. Теоретические аспекты формирования инвестиционного портфеля предприятия. 214

Нургабылов М.Н., Барлыков Е.К., Егембердиева С.M. Тенденции управления развитием мясоперерабаты-

вающей отрасли в РК.

Нурымбетов Т.Я., Абишова А.У., Уразбаева Г.Ж., Кыдырова Ж.Ш., Байнеева П.Т., Абишов Н.У. Приоритеты

социальной поддержки населения РК в условиях модернизации................................................................................. 22

Рахимова С. А., Тургумбекова М. М. Программы государственной поддержки мсб в республике Казахстан и меры

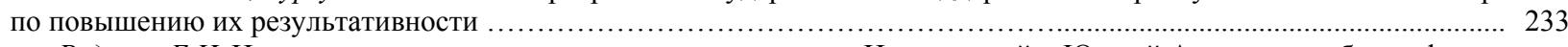

Руденко Е.И. Искаженность восприятия между государствами Центральной и Южной Азии как проблема фактора

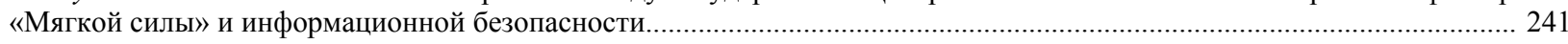

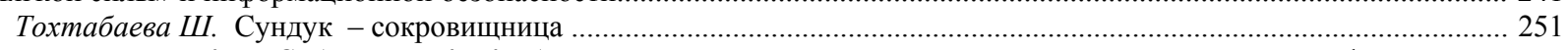

Утепкалиева К.М., Сабирова Р.К., Кенбаева Г.У.Развитие государственно-частного партнерства в нефтегазовой

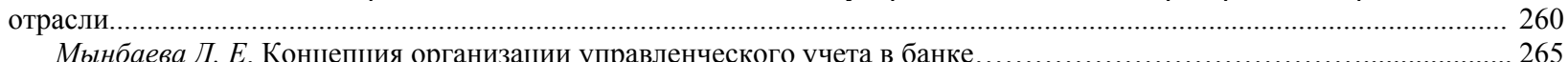

Мынбаева Д. Е. Концепция организации управленческого учета в банке...........................................2.
Султанова Г.С. Педагогические аспекты формирования профессиональных компетенций бакалавра - экономиста

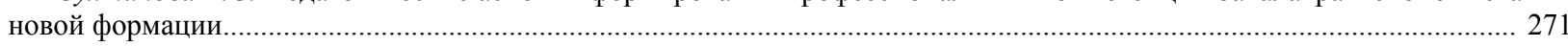

Шаяхметова А.А. О подготовке педагогических кадров к инклюзивному образованию в условиях вуза................ 277 


\section{CONTENTS}

Bespayeva R.S., Bugubayeva R.O., Manuel F. Grela. Formation of the complex strategy for development of the Schuchinsk-

Burabay resort area based on the balanced system of indicators.

Ayupova Z.K., Kussainov D.U., Winston Nagan. Some facets of integration in themodernization ofthe civil process..............13

Kussainova A.A., Kozlowski Waldemar, Gerashchenko I.P. The review of some features of the financial legal mechanism of obligatory social insurance in the republic of Kazakhstan...

Dyussenov B.D. Linguistic features of epigraphic monuments................................................................................ 28

Jumadilova Sh.G., Atabay B.Zh. Dynamics of the population savings in Kazakhstan.......................................................... 33

Karabalina A.A., Alsitova A.B., Kereimaganbetova Zh.N., Abisheva N.M. The values as critical factor of moral education... 42

Kenzhebayeva D.K., Urmurzina B.G., Dashqin Mahammadli. The modern youth values in Kazakhstan............................. 51

Nurmanova A.S., Mederova D.E., Dyussenov B.D. "Bokeykhanov dynasty taldybeyit necropolis" epigraphic monuments

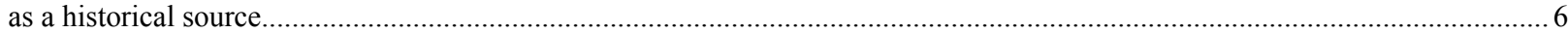

Kydyrova Zh.Sh., Onlasynov E.Z., Abishova A.U., Shadieva A.A.Research of the situation in the market of milk and dairy

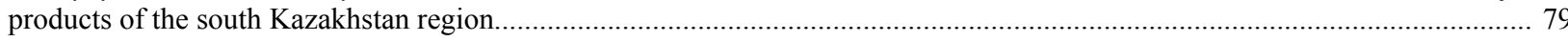

Abishova G.U., Amanzholov R.A., Mynbayeva B.N., Ibragimova D.I. Readiness of students-biologists for the organization

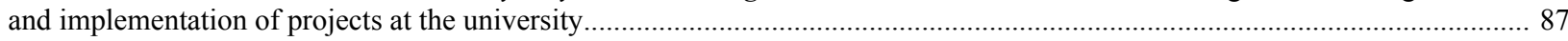

Baltabayeva A.Y., Rizakhojayeva $G$. The phenomenon of the great silk road in the cultural integration process................... 91

Burganova R.I., Abdugalina S.E., Tuyakova A.E. Improving the quality of education through student-centered education... 102

Galiyeva A.Kh., Sadu Zh.N., Kulubekov M.T., Kazbekova L.A. Assessment of the institutional terms of the foreign

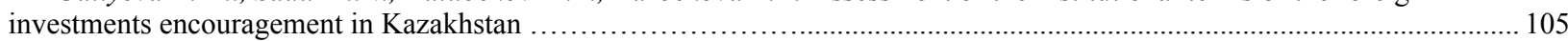

Dzhalilov Z.G. Theoretical discourse on islam and politics in foreign humanism of the second half of 20th century.......... 112

Dzhumabekova A.T., Kanatova A.ZH. Transformation of the transmission mechanism of the national bank of the republic

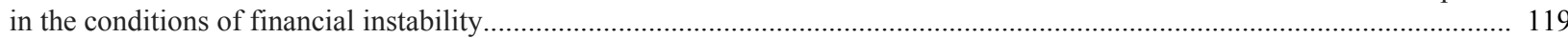

Suleimenov R.B. Problems and features of the development of migration processes in Kazakhstan and Central Asia.......... 124

Yesengulova M.N. Psychological aspects of reintegration and resocialization of "Trouble" adolescents in Kazakhstan....... 134

Zhakisheva K.M., Zhumanova D.T., Mukasheva G.M.The role of monitoring the financial condition of agricultural

enterprises in ensuring sustainable development of the agrarian sector of the economy......................................................... 146

Zhakhina B.B. Principles of functional literacy formation of the kazakh language....................................................... 151

Idresova U.Kh., Saduahasova Z.Zh., Mukhanova A.T. Criminalistics............................................................................. 156

Savelyeva $V . V$. Historicalandpedagogical bases of formation and development of credit technology in Kazakhstan........... 160

Kaliyeva T.M., Sembiyeva L.M. National Resources and national wealth.................................................................. 165

Karimova R., Hajiyeva G. Examining ethno-political and SOCIO-economic transformation of the xinjiang uyghur

autonomous region in the context of the PRC national policies........................................................................................ 176

Kerimbek G., Moldashbayeva L., Jrauova K., Azhmukhamedova A., Misanova A. Analysis and evaluation of reduction

of tax recovery of the republic of kazakhstan on the budget of the republic of Kazakhstan................................................. 185

Zholdasbekova S.A., Parmankulova P.Zh., Assanaliyev M.K. Folk games in the education of children with physical, mental and sensory disturbances..

Moldakenova E.K., Baygabulova K.K., Onaeva B.T. Ways of development of the system of the regional aspect of managing innovative processes in the APC.

Muratova G.K., Shaushenova A.G., Zhumassseitova C.D., Ongarbayeva M.B. Application of cloud technologies in the educational process......

Nurgabylov M.N., Barlikov E.K., Egemberdieva S.M. Trends of management of the development of meat processing industry in RK

Nurymbetov T.Ya., Abishova A.U., Urazbaeva G.Zh., Kydyrova Z.Sh., Baineeva P.T., Abishov N.U. Priorities of social support of the population of republic of Kazakhstan in the conditions of modernization........

Rakhimova S. A., Turgumbekova M. M. Programs of government support for sme in the republic of Kazakhstan and measures to enhance their efficiency.....

Rudenko Ye.I. Misperception between the states of Central and South Asia as a 'Soft power' and information security issue...

Tokhtabayeva Sh. Zh. Treasure-chest.

Utepkalieva K.M., Sabirova R.K., Kenbaeva G.U.Development of public private partnership approach in oil and gas

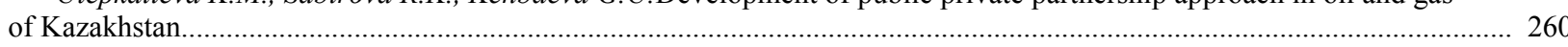

Mynbayeva D.E. Concept of organization of management accounting in bank ........................................................... 265

Sultanova G. S. Pedagogical aspects of formation of professional competence of the bachelor-economist of the new formation

Shayakhmetova A.A. On the training of teaching staff for inclusive education under the conditions of higher education institution. 


\section{PUBLICATION ETHICS AND PUBLICATION MALPRACTICE IN THE JOURNALS OF THE NATIONAL ACADEMY OF SCIENCES OF THE REPUBLIC OF KAZAKHSTAN}

For information on Ethics in publishing and Ethical guidelines for journal publication see http://www.elsevier.com/publishingethics and http://www.elsevier.com/journal-authors/ethics.

Submission of an article to the National Academy of Sciences of the Republic of Kazakhstan implies that the work described has not been published previously (except in the form of an abstract or as part of a published lecture or academic thesis or as an electronic preprint, see $\mathrm{http} / / / \mathrm{www} . e l s e v i e r . c o m / p o s t i n g p o l i c y)$, that it is not under consideration for publication elsewhere, that its publication is approved by all authors and tacitly or explicitly by the responsible authorities where the work was carried out, and that, if accepted, it will not be published elsewhere in the same form, in English or in any other language, including electronically without the written consent of the copyrightholder. In particular, translations into English of papers already published in another language are not accepted.

No other forms of scientific misconduct are allowed, such as plagiarism, falsification, fraudulent data, incorrect interpretation of other works, incorrect citations, etc. The National Academy of Sciences of the Republic of Kazakhstan follows the Code of Conduct of the Committee on Publication Ethics (COPE), and follows the COPE Flowcharts for Resolving Cases of Suspected Misconduct (http://publicationethics.org/files/u2/New_Code.pdf). To verify originality, your article may be checked by the originality detection service Cross Check http://www.elsevier.com/editors/plagdetect.

The authors are obliged to participate in peer review process and be ready to provide corrections, clarifications, retractions and apologies when needed. All authors of a paper should have significantly contributed to the research.

The reviewers should provide objective judgments and should point out relevant published works which are not yet cited. Reviewed articles should be treated confidentially. The reviewers will be chosen in such a way that there is no conflict of interests with respect to the research, the authors and/or the research funders.

The editors have complete responsibility and authority to reject or accept a paper, and they will only accept a paper when reasonably certain. They will preserve anonymity of reviewers and promote publication of corrections, clarifications, retractions and apologies when needed. The acceptance of a paper automatically implies the copyright transfer to the National Academy of sciences of the Republic of Kazakhstan.

The Editorial Board of the National Academy of sciences of the Republic of Kazakhstan will monitor and safeguard publishing ethics. 
Правила оформления статьи для публикации в журнале смотреть на сайте:

\section{www:nauka-nanrk.kz}

\section{social-human.kz}

Редакторы М.С. Ахметова, Т.А. Апендиев, Д.С. Аленов

Верстка на компьютере А.М. Кульгинбаевой

Подписано в печать 08.12.2018

Формат 60x881/8. Бумага офсетная. Печать - ризограф.

17,7 п.л. Тираж 500. Заказ 6.

Национальная академия наук $Р К$

050010, Алматы, ул. Шевченко, 28, т. 272-13-18, 272-13-19 